\title{
Penentuan Lokasi Industri Olahan Karet UIKM di Kabupaten Sijunjung
}

\author{
Shelly Christina ${ }^{1}$, Bitta Pigawati ${ }^{2}$
}

Diterima : 24 Desember 2014

Disetujui : 7 Januari 2015

\begin{abstract}
Rubber plantation is one of superior commodity and main-livelihood in community of Sijunjung regency. Rubber product that is managed by community currently is in the form of rubber-slab without further processing because of industrial-processing unavailability in Sijunjung regency. Therefore, it causing long list of market-chain and price that is obtained by farmer become 50-55\% of factory-price. The purpose of this research is to determine the location of SME rubber-processing industry in Sijunjung regency. Research methodology implemented here was descriptive-quantitative with scoring and weighted overlay techniques. Analysis was conducted by consideration of conformity variable of SME rubber-processing industry area, accessibility, supporting-facility, value of land, transportation expense, and Urban Planningpolicies in Sijunjung regency. Research finding shows that there are seven districts and 31 villages (Nagari) considered to be compatible for SME rubberprocessing industry location. However, the most recommended district from these seven districts that are Kamang Baru in particularly Nagari (village) Takung and Sungai Lansek, because these villages have permission from local government to develop agro-industry and produce majority of rubber-product in Sijunjung regency, and also passing by primary road, electricity and fresh water source.
\end{abstract}

Key words : industrial location, rubber, SME, land compatibility, accessibility, supporting-facility, land value, transportation expense, SIG

\begin{abstract}
ABSTRAK
Perkebunan karet merupakan salah satu komoditi unggulan dan sumber mata pencaharian utama masyarakat di Kabupaten Sijunjung. Hasil produksi karet yang dikelola oleh masyarakat pada saat ini masih dalam bentuk slab/ojol (bekuan karet) tanpa pengolahan lebih lanjut dikarenakan belum tersedianya industri pengolahan karet di Kabupaten Sijunjung, sehingga mengakibatkan rantai pemasaran menjadi cukup panjang dan harga yang diterima petani berkisar 50-55\% dari harga pabrik. Tujuan dari penelitian ini adalah penentuan lokasi industri olahan karet UIKM di Kabupaten Sijunjung. Metode penelitian yang digunakan adalah kuantitatif deskriptif dengan teknik pembobotan (scoring) dan weighted overlay. Analisis dilakukan dengan mempertimbangkan variabel kesesuaian lahan industri olahan karet UIKM, aksesibilitas, sarana pendukung, nilai lahan, biaya transportasi dan kebijakan RTRW Kabupaten Sijunjung. Hasil penelitian menunjukkan bahwa terdapat 7 Kecamatan dan 31 Nagari yang sesuai menjadi lokasi industri olahan karet UIKM. Namun dari 7 Kecamatan tersebut, daerah yang paling direkomendasikan adalah Kecamatan Kamang Baru terutama Nagari Takung dan Sungai Lansek karena daerah tersebut merupakan daerah yang diizinkan oleh Pemerintah Daerah untuk pembangunan agroindustri dan menjadi penghasil karet terbanyak di Kabupaten Sijunjung serta dialiri oleh jaringan jalan arteri primer, listrik dan memiliki sumber air bersih.
\end{abstract}

Kata kunci : lokasi industri, karet, UIKM, kesesuaian lahan, aksesibilitas, sarana pendukung, nilai lahan, biaya transportasi

\footnotetext{
${ }^{1}$ Mahasiswa Magister Pembangunan Wilayah dan Kota, Undip, Semarang, Jawa Tengah

2 Dosen Jurusan Perencanaan Wilayah dan Kota, Undip, Semarang, Jawa Tengah

Kontak Penulis : shellychristina01@gmail.com
} 


\section{PENDAHULUAN}

Pemberlakuan otonomi daerah menuntut setiap Pemerintah Daerah dapat mengembangkan berbagai potensi unggulan daerah agar mampu meningkatkan PDRB daerah dan kesejahteraan masyarakat. Salah satu sektor yang memberikan peranan cukup besar dalam peningkatan PDRB daerah adalah sektor pertanian terutama subsektor perkebunan. Integrasi antara sektor pertanian dan industri diharapkan memberikan nilai tambah dan daya jual yang tinggi. Namun kegiatan industri pengolahan hasil pertanian masih bertumpu pada daerah perkotaan sedangkan daerah hinterland (Kabupaten) lebih berperan dalam penyediaan (supply) bahan baku pertanian. Berdasarkan hal tersebut maka Pemerintah Daerah mengembangkan kegiatan UIKM (Usaha Industri Kecil dan Menengah) yang pengelolaan usahanya dilakukan oleh para petani (masyarakat) bekerjasama dengan pihak pemerintah. Selain itu sifat produk pertanian yang mudah rusak dan bulky perlu diperhatikan dalam perencanaan lokasi industri pengolahan. Lokasi industri harus memberikan unit cost terendah atau memberikan efisiensi yang maksimum agar dapat mendorong pertumbuhan ekonomi wilayah.

Pada saat ini sektor pertanian khususnya sub sektor perkebunan karet merupakan mata pencaharian utama masyarakat di Kabupaten Sijunjung dengan luas areal perkebunan rata-rata 2 Ha. Namun pada saat ini slab/ojol belum diproses lebih lanjut dikarenakan industri pengolahan karet yang belum tersedia di Kabupaten Sijunjung sehingga mengakibatkan rantai pemasaran menjadi cukup panjang dan harga yang diterima petani cukup rendah. Menyadari hal tersebut maka Pemerintah Daerah Kabupaten Sijunjung telah merencanakan pembangunan kawasan peruntukan industri di Kecamatan Kamang Baru dan IV Nagari sebagaimana yang tertuang dalam RTRW Kabupaten Sijunjung Tahun 2011-2030. Namun dalam pemilihan lokasi industri tersebut belum secara rinci mempertimbangkan aspek kesesuaian lahan, aksesibilitas, sarana pendukung, serta nilai lahan. Berdasarkan latar belakang dan perumusan masalah tersebut maka ditetapkan tujuan dari penelitian ini adalah mengkaji penentuan lokasi industri pengolahan karet UIKM di Kabupaten Sijunjung.

\section{METODE PENELITIAN}

Metode penelitian yang digunakan adalah kuantitatif deskriptif yang didasarkan pada sesuatu yang empirik. Kuantitatif deskriptif didasarkan pada fakta-fakta dari objek yang diamati dengan tujuan membuat deskripsi, gambaran secara sistematis, faktual dan akurat.

\section{GAMBARAN UMUM}

Kabupaten Sijunjung merupakan salah satu Kabupaten yang terletak di bagian Timur Provinsi Sumatera Barat dan menjadi jalur utama penghubung antara Provinsi Riau dan Provinsi Jambi. Kabupaten Sijunjung pada saat ini terdiri dari 8 Kecamatan, 60 Nagari dan 1 desa dengan 280 Jorong dan 1 dusun. Secara umum penggunaan lahan di Kabupaten Sijunjung didominasi oleh hutan (51\%) dan pertanian/perkebunan dengan luas sekitar $47 \%$ dari luas wilayah Kabupaten Sijunjung. Topografi Kabupaten Sijunjung memiliki ciri yang berbukit-bukit dengan tingkat kemiringan/kelerengan yang bervariasi.Selain itu Kabupaten Sijunjung memiliki curah hujan rata-rata $2.451 \mathrm{~mm} /$ tahun dandidominasi oleh jenis bebatuan batu apung tufa $(24,45 \%)$ serta dilalui oleh 3 DAS (DAS Batanghari, Indragiri, dan Kampar). 


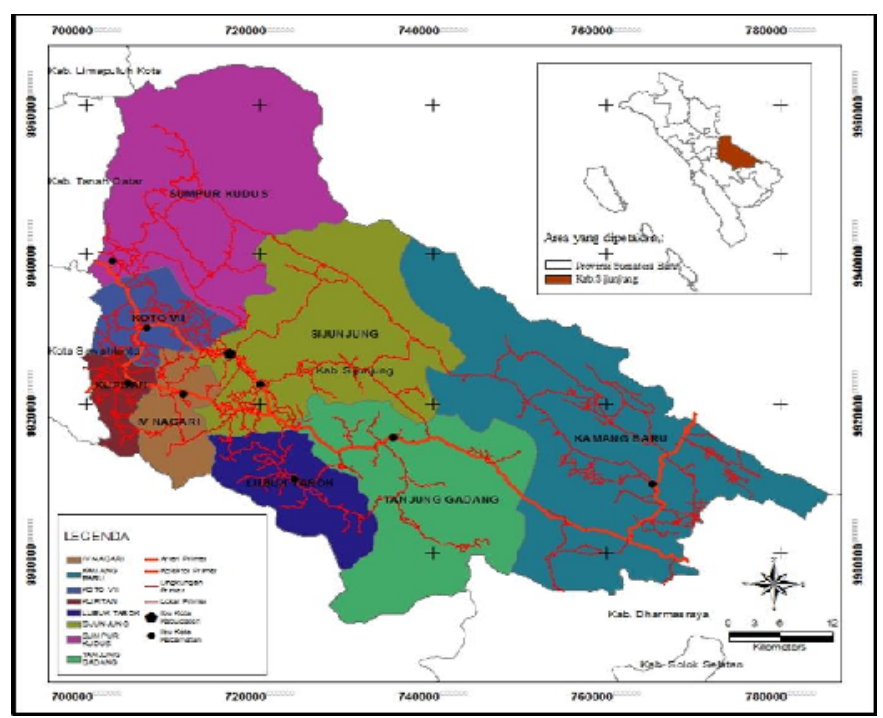

Sumber: Bappeda, 2013

\section{GAMBAR 1}

PETA ADMMINISTRASI KABUPATEN SIJUNJUNG

Salah satu tiang perekonomian di Kabupaten Sijunjung adalah perkebunan karet. Luas lahan perkebunan yang dikelola secara intensif di Kabupaten Sijunjung adalah 120.358 ha atau $38,44 \%$ dari total luas wilayah. Produksi karet tertinggi berada di Kecamatan Kamang Baru yaitu 16.627 ton atau 33,18\% dari produksi total Kabupaten. Perkebunan karet di Kabupaten Sijunjung keseluruhannya dikelola oleh rakyat dengan luas lahan rata-rata \pm 2 Ha dan produksi rata-rata 50-150 kg/minggu. Pada umumnya masyarakat menggunakan sepeda motor atau mobil pick up L300 untuk mengangkut slab/ojol dari perkebunan karet dan biasanya melalui jalan arteri, kolektor dan lokal primer. Rantai pemasaran karet di Kabupaten Sijunjung terdiri dari petani, pedagang pengumpul keliling, pedagang pengumpul tingkat kecamatan dan pabrik. Rata-rata harga yang diterima oleh para petani $\mathrm{Rp} 6.000,-/ \mathrm{kg}$ hingga $\mathrm{Rp} 7.000,-/ \mathrm{kg}$ tergantung dari kualitas slab/ojol.

\section{KAJIAN TEORI}

Dari sudut pandang geografi industri, industri merupakan integrasi antara komponenkomponen fisik alam seperti bahan baku, topografi, geologi dan sebagainya dengan subsistem manusia yang terdiri dari tenaga kerja, mesin dan peralatan, transportasi, kebijakan pemerintah, dan sebagainya untuk mendukung pertumbuhan dan perkembangan industri. Penentuan lokasi industri merupakan elemen penting dalam perekonomian wilayah terutama yang berkaitan dengan aspek tata ruang. Pemilihan lokasi yang baik akan memberikan efisiensi dalam bidang produksi maupun pemasaran sehingga pada akhirnya dapat mendorong pertumbuhan ekonomi wilayah (Syafrizal, 2008). Salah satu pelopor teori lokasi yaitu Alfred Weber yang menganalisis pemilihan lokasi industri berdasarkan 3 faktor yaitu biaya transportasi, biaya tenaga kerja dan aglomerasi. Selain ketiga faktor tersebut terdapat beberapa faktor lain seperti bahan mentah, tenaga kerja, transportasi, aksesibilitas, ketersediaan sarana pendukung, harga lahan, topografi, Peraturan Pemerintah, dan sebagainya (Soehardi, 1987: 43-44). 
Karet merupakan salah satu komoditi ekspor yang mempunyai peranan penting bagi perekonomian Indonesia.Tanaman karet memiliki keunggulan antara lain persyaratan tumbuh yang lebih mudah dibandingkan tanaman lainnya, dapat dikelola sendiri oleh masyarakat, tersebar dalam skala luas serta mampu memperbaiki kondisi hidrologis pada lahan kritis dan memperbaiki serta melestarikan lingkungan hidup. Pada saat ini produksi karet rakyat biasanya masih berupa slab/ojolatau dikenal dengan sebutan bokar (bahan olahan karet rakyat). Bokar tersebut selanjutnya diolah menjadi karet remah (crumb rubber) oleh industri pengolahan karet yang terdapat di daerah ibukota Propinsi (luar Kabupaten).Proses bokar (slab/ojol) sampai ke pabrik pengolahan harus melalui rantai pemasaran yang cukup panjang sehingga harga yang diterima petani cukup rendah (50\% dari harga pabrik).

Salah satu program Pemerintah Daerah yang mampu menjawab permasalahan tersebut adalah industri olahan karet UIKM (Usaha Industri Kecil dan Menengah). Beberapa keunggulan dari UIKM antara lain menggunakan modal yang tidak terlalu besar (kurang dari 500 juta) dan teknologi yang sederhana, memanfaatkan bahan baku lokal, luas lahan berkisar $1 \mathrm{Ha}$ atau lebih dan tenaga kerja berjumlah 5-99 orang. Pembangunan industri olahan karet UIKM biasanya mempertimbangkan beberapa faktor berikut (Siswita, 2013):

1. Sumber air: air umpan boiler, dan untuk air pengolahan

2. Jauh dari permukiman: slab/ojol memiliki bau yang menyengatsehingga dapat mengganggu kenyamanan masyarakat di sekitarnya.

3. Dekat dengan bahan baku: agar dapat meminimasi biaya transportasi.

4. Keadaan tanah lokasi: bukan daerah rawan bencana banjir dan longsor.

5. Ada aliran sungai: berfungsi untuk mengalirkan limbah cair (sudah diolah).

6. Ketersediaan sarana dan prasana jalan: mempermudah distribusi bahan baku dan barang jadi karet.

7. Tenaga kerja: \pm 5 orang (berdasarkan studi banding pada CV. Batang Ombilin).

\section{ANALISIS}

Analisis penentuan lokasi industri olahan karet UIKM di Kabupaten Sijunjung menggunakan bantuan Sistem Informasi Georgrafis (SIG) yang memadukan data spasial dan non spasial, melalui Spatial Analyst. Data-data dari masing-masing variabel penelitian seperti variabel kesesuaian lahan, sarana pendukung, aksesibilitas, nilai lahan, dan variabel biaya transportasi minimum diberi bobot (scoring) sesuai dengan kelas data. Bobot yang digunakan sesuai dengan skala Likert, nilai 1-5 dengan nilai 1 untuk kelas ketidaksesuaian dan 5 untuk kelas kesesuaian.

\section{Analisis Kesesuaian Lahan Industri Olahan Karet}

Analisis kesesuaian lahan industri olahan karet UIKM dalam penelitian ini menggunakan metode scoring untuk menilai potensi lahan yaitu dengan memberikan bobot (skor) masingmasing indikator.

TABEL 1

SKOR VARIABEL KESESUAIAN LAHAN

\begin{tabular}{|l|l|l|l|c|}
\hline No & Indikator & Kategori & Kriteria & Skor \\
\hline \multirow{4}{*}{1.} & Kemiringan lereng & Curam & $25-40 \%$ & 1 \\
\cline { 3 - 5 } & & Agak curam & $15-25 \%$ & 2 \\
\cline { 3 - 5 } & & Landai & $8-15 \%$ & 3 \\
\cline { 3 - 5 } & Datar & $<8 \%$ & 4 \\
\hline
\end{tabular}




\begin{tabular}{|c|c|c|c|c|}
\hline No & Indikator & Kategori & Kriteria & Skor \\
\hline \multirow[t]{5}{*}{2.} & Curah hujan & $\begin{array}{l}\text { Sangat } \\
\text { tinggi }\end{array}$ & $3500-4000 \mathrm{~mm} / \mathrm{thn}$ & 1 \\
\hline & & Tinggi & $3000-3500 \mathrm{~mm} / \mathrm{thn}$ & 2 \\
\hline & & Sedang & $2500-3000 \mathrm{~mm} / \mathrm{thn}$ & 3 \\
\hline & & Rendah & 2000-2500 mm/thn & 4 \\
\hline & & $\begin{array}{l}\text { Sangat } \\
\text { rendah }\end{array}$ & $1500-2000 \mathrm{~mm} / \mathrm{thn}$ & 5 \\
\hline \multirow[t]{4}{*}{3.} & Geologi & Peka & $\begin{array}{l}\text { Andosol, lateric, grumosol, podsol, } \\
\text { podsolic }\end{array}$ & 1 \\
\hline & & Cukup peka & $\begin{array}{l}\text { Brown forest soil, non calcic brown, } \\
\text { mediteran }\end{array}$ & 2 \\
\hline & & Agak peka & Latosol & 3 \\
\hline & & Tidak peka & $\begin{array}{l}\text { Alluvial, tanah glei, planosol, } \\
\text { hidromorf kelabu, laterik air tanah }\end{array}$ & 4 \\
\hline \multirow[t]{3}{*}{4.} & Tata guna lahan & Tidak sesuai & Hutan, permukiman, sawah & 1 \\
\hline & & Agak sesuai & $\begin{array}{l}\text { Kebun campuran, perairan darat, } \\
\text { perkebunan, tambang }\end{array}$ & 3 \\
\hline & & Sesuai & Tanah terbuka, semak/belukar & 5 \\
\hline \multirow[t]{2}{*}{5.} & Produksi Karet & Rendah & Rata-rata produksi karet $<14 \%$ & 1 \\
\hline & & Sedang & Rata-rata produksi karet $14-23 \%$ & 3 \\
\hline \multirow[t]{3}{*}{6.} & Jarak terhadap & Dekat & Jarak $<1 \mathrm{~km}$ dari permukiman & 1 \\
\hline & permukiman & Sedang & Jarak 1-2 km dari permukiman & 3 \\
\hline & & Jauh & Jarak > 2 km dari permukiman & 5 \\
\hline \multirow[t]{3}{*}{7.} & $\begin{array}{l}\text { Jarak terhadap } \\
\text { sungai }\end{array}$ & Jauh & Jarak < $100 \mathrm{~m}$ dan > 5 km dari sungai & 1 \\
\hline & & Sedang & Jarak $2-5$ km dari sungai & 3 \\
\hline & & Dekat & Jarak $100 \mathrm{~m}-2 \mathrm{~km}$ dari sungai & 5 \\
\hline \multirow[t]{3}{*}{8.} & $\begin{array}{l}\text { Jumlah petani } \\
\text { karet }\end{array}$ & Sedikit & Jumlah petani karet $<11 \%$ & 1 \\
\hline & & Sedang & Jumlah petani karet $11-18 \%$ & 3 \\
\hline & & Banyak & Jumlah petani karet > $18 \%$ & 5 \\
\hline \multirow[t]{2}{*}{9.} & $\begin{array}{l}\text { Daerah rawan } \\
\text { bencana }\end{array}$ & Tidak sesuai & Rawan bencana & 1 \\
\hline & & Sesuai & Bebas rawan bencana & 5 \\
\hline
\end{tabular}

Sumber: Hasil Analisis, 2014

\section{Analisis Sarana Pendukung}

Analisis ini bertujuan untuk mengetahui ketersediaan sumber-sumber yang dapat menunjang keperluan teknis industri seperti jaringan listrik dan sumber air. Kedua indikator ini dibagi menjadi beberapa kelas data sesuai dengan kriteria yang ditentukan.

TABEL 2

SKOR VARIABEL SARANA PENDUKUNG

\begin{tabular}{|l|l|l|l|c|}
\hline No & \multicolumn{1}{|c|}{ Indikator } & \multicolumn{1}{|c|}{ Kategori } & \multicolumn{1}{|c|}{ Kriteria } & Skor \\
\hline 1. & Jaringan & Tidak sesuai & Tidak terjangkau oleh jaringan listrik & 1 \\
\hline & $\ldots . .$. & Sesuai & Terjangkau oleh jaringan listrik & 5 \\
\hline 2. & $\begin{array}{l}\text { Sumber air } \\
\text { bersih } \\
\text { (PDAM }\end{array}$ & Tidak sesuai & Tidak ada sumber air bersih (PDAM) & 1 \\
\cline { 2 - 5 } & Sesuai & Ada sumber air bersih (PDAM) & 5 \\
\hline
\end{tabular}

Sumber: Hasil Analisis, 2014 
Hasil analisis berdasarkan ketersediaan jaringan listrik menunjukkan bahwa hampir seluruh Kecamatan di Kabupaten Sijunjung telah dialiri listrik kecuali satu Nagari yaitu Lubuk Tarantang di Kecamatan Kamang Baru (skor 1). Begitu juga dengan sumber air bersih (PDAM) yang telah tersedia pada sebagian besar Kecamatan kecuali Kecamatan Sijunjung (Nagari Paru, Solok Amba, Aia Angek dan Pematang Panjang) dan Kecamatan Kamang Baru (Nagari Kamang Baru).

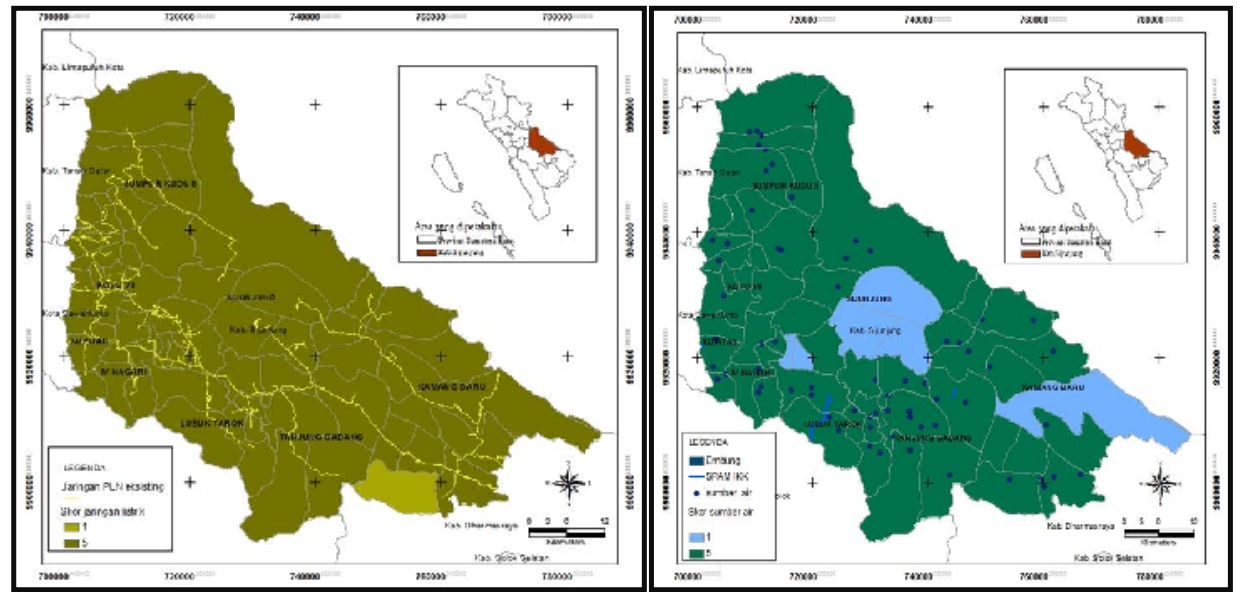

Sumber: Hasil Analisis, 2014

GAMBAR 2

PETA SKOR JARINGAN LISTRIK DAN PETA SKOR SUMBER AIR BERSIH (PDAM)

\section{Analisis Aksesibilitas}

Analisis aksesibilitas bertujuan untuk mengetahui tingkat aksesibilitas lokasi industri karet dari jalan. Adapun indikator yang digunakan dalan analisis aksesibilitas ini adalah sarana jalan dan fungsi jalan. Pada saat ini proses pengangkutan bahan baku mapun produk jadi karet biasanya masih menggunakan sepeda motor dan mobil pick up dan belum terdapat jalur khusus untuk proses distribusi barang di Kabupaten Sijunjung. Oleh karena itu pada penelitian ini fungsi jaringan jalan yang dipertimbangkan pada pemilihan lokasi industri olahan karet terdiri dari tiga yaitu arteri primer, kolektor primer dan lokal primer.

TABEL 3

SKOR VARIABEL AKSESIBILITAS

\begin{tabular}{|c|c|c|c|c|}
\hline No & Indikator & Kategori & Kriteria & Skor \\
\hline \multirow[t]{5}{*}{1.} & \multirow[t]{5}{*}{ Sarana jalan } & Sangat jauh & $>2000 \mathrm{~m}$ & 1 \\
\hline & & Jauh & $1500-2000 \mathrm{~m}$ & 2 \\
\hline & & Sedang & $1000-1500 \mathrm{~m}$ & 3 \\
\hline & & Dekat & $500-1000 \mathrm{~m}$ & 4 \\
\hline & & Sangat dekat & $0-500 \mathrm{~m}$ & 5 \\
\hline \multirow[t]{3}{*}{2} & \multirow[t]{3}{*}{ Fungsi jalan } & Kurang baik & Terkait dengan lokal primer & 1 \\
\hline & & Cukup baik & $\begin{array}{l}\text { Terkait dengan kolektor } \\
\text { primer }\end{array}$ & 3 \\
\hline & & Sangat baik & $\begin{array}{l}\text { Terkait dengan jalan arteri } \\
\text { primer }\end{array}$ & 5 \\
\hline
\end{tabular}

Sumber: Hasil Analisis, 2014

Analisis sarana jalan dimulai dengan melakukan multiple ring buffer pada analyst tools dengan jarak 500 m, 1000 m, 1500 m, 2000 m untuk mengetahui kedekatan calon lokasi industri olahan karet dari jaringan jalan. Sedangkan analisis fungsi jalan menggunakan 
peta administrasi Nagari yang ditampalkan (overlay) dengan peta jaringan jalan. Hasil analisis kedua indikator ini dapat dilihat pada Gambar 3.

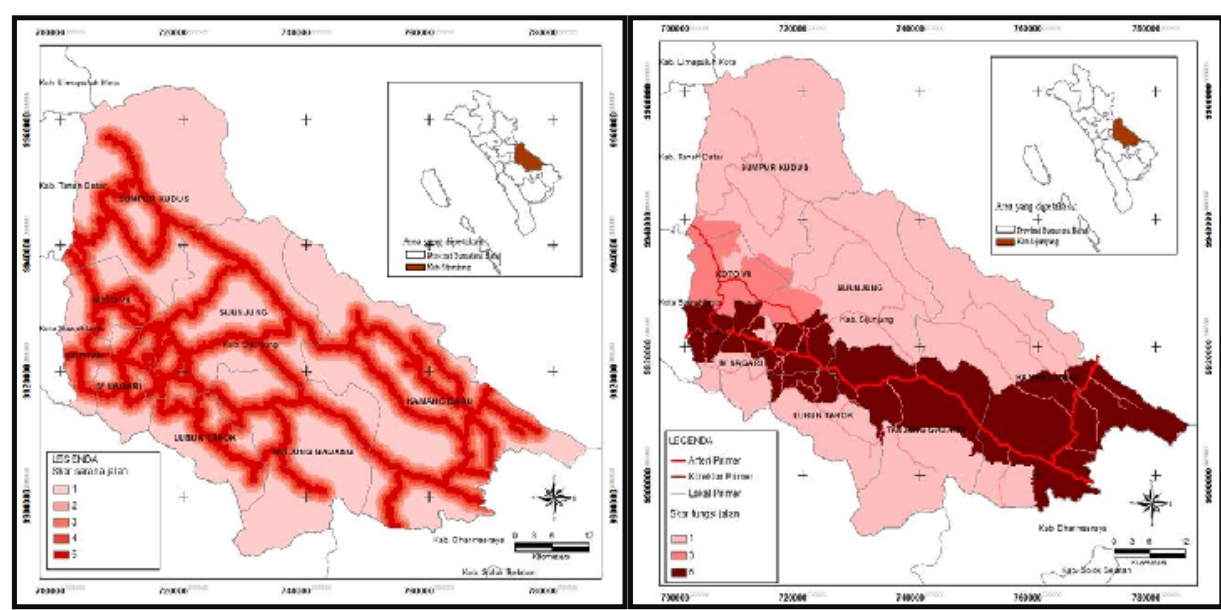

Sumber: Hasil Analisis, 2014

GAMBAR 3

PETA SKOR SARANA JALAN DAN SKOR FUNGSI JALAN

\section{Analisis Nilai Lahan}

Analisis nilai lahan bertujuan agar lokasi terpilih memiliki nilai lahan yang paling minimum. Nilai lahan dalam penelitian ini menggunakan beberapa pendekatan yaitu kedekatan dengan infrastruktur dan kedekatan dengan jaringan jalan. Semakin dekat daerah calon lokasi industri olahan karet dengan jaringan jalan dan infrastruktur maka nilai lahan diasumsikan akan semakin tinggi dan sebaliknya. Skor untuk masing-masing indikator nilai lahan dapat dilihat pada Tabel 4.

TABEL 4

SKOR VARIABEL NILAI LAHAN

\begin{tabular}{|l|l|l|l|l|}
\hline No & Indikator & Kategori & Kriteria & Skor \\
\hline \multirow{3}{*}{1.} & \multirow{2}{*}{$\begin{array}{l}\text { Kedekatan dengan } \\
\text { jaringan jalan }\end{array}$} & Cukup tinggi & $0-500 \mathrm{~m}$ & 1 \\
\cline { 3 - 5 } & & Tinggi & $500-1.000 \mathrm{~m}$ & 2 \\
\cline { 3 - 5 } & & Sedang & $1.000-1.500 \mathrm{~m}$ & 3 \\
\cline { 3 - 5 } & Rendah & $1.500-2.000 \mathrm{~m}$ & 4 \\
\cline { 3 - 5 } & & Cukup rendah & $>2.000 \mathrm{~m}$ & 5 \\
\hline \multirow{2}{*}{ 2. } & \multirow{2}{*}{$\begin{array}{l}\text { Kedekatan dengan } \\
\text { infrastruktur }\end{array}$} & Tinggi & $0-1 \mathrm{~km}$ & 1 \\
\cline { 3 - 5 } & Sedang & $1-2 \mathrm{~km}$ & 3 \\
\cline { 3 - 5 } & Rendah & $>2 \mathrm{~km}$ & 5 \\
\hline
\end{tabular}

Analisis nilai lahan berdasarkan kedekatan dengan jaringan jalan dilakukan melalui proses multiple ring buffer jaringan jalan dengan kriteria jarak 500, 1.000, 1500, dan $2.000 \mathrm{~m}$. Proses yang sama juga dilakukan pada analisis nilai lahan berdasarkan kedekatan dengan infrastruktur dengan jarak $1 \mathrm{~km}, 2 \mathrm{~km}$ dan lebih dari $2 \mathrm{~km}$ terhadap point-point infrastruktur. Hasil analisis ini dapat dilihat pada Gambar 4. 


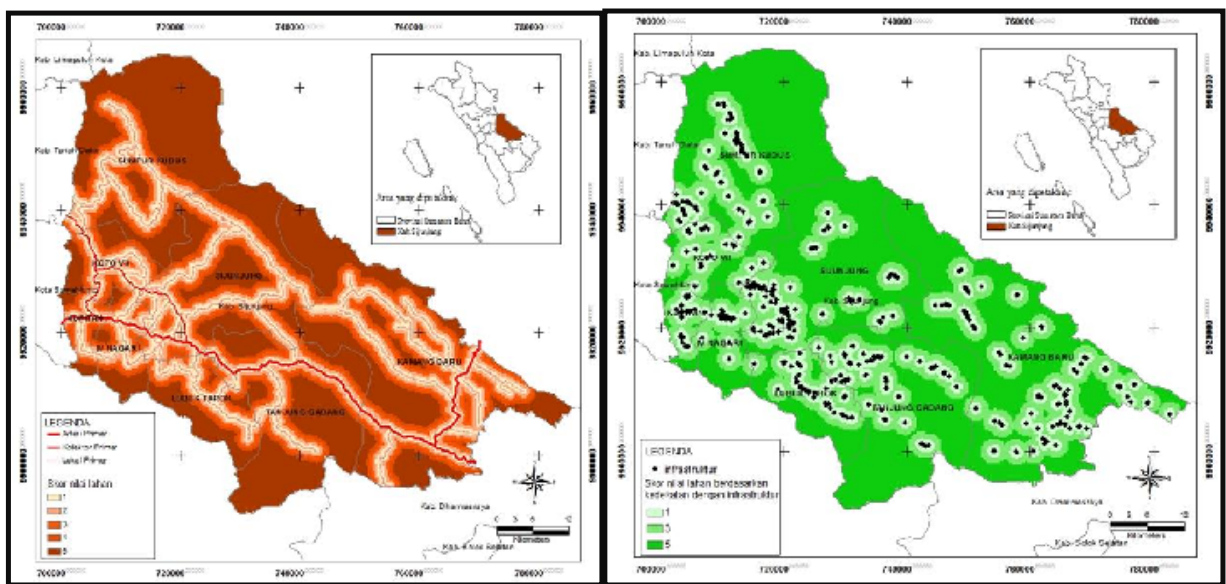

Sumber : Hasil Analisis, 2014

GAMBAR 4

PETA SKOR NILAI LAHAN BERDASARKAN KEDEKATAN JARINGAN JALAN DAN KETERSEDIAAN INFRASTRUKTUR

\section{Analisis Biaya Transportasi Minimum}

Setelah didapatkan skor untuk masing-masing indikator pada setiap variabel, maka tahap selanjutnya adalah merubah masing-masing data setiap indikator dari bentuk vektor ke raster (convert to raster). Data yang telah dirubah ke dalam raster kemudian diberi bobot yang dilakukan secara subjektif berdasarkan pengaruh setiap indikator terhadap lokasi industri olahan karet. Pada Tabel 5 dapat dilihat bobot masing-masing variabel dan indikator.

TABEL 5

BOBOT VARIABEL DAN INDIKATOR

\begin{tabular}{|l|r|r|}
\hline \multicolumn{1}{|c|}{ Variabel dan Indikator } & \multicolumn{1}{|c|}{ Bobot } & Kriteria \\
\hline Kesesuaian Lahan & $\mathbf{5 8} \%$ & \\
\hline Curah Hujan & $\mathbf{7 \%}$ & Cukup berpengaruh \\
\hline Geologi (Jenis Tanah) & $\mathbf{4 \%}$ & Kurang berpengaruh \\
\hline Tata Guna Lahan & $5 \%$ & Kurang berpengaruh \\
\hline Produksi Karet & $\mathbf{7 \%}$ & Cukup berpengaruh \\
\hline Jarak terhadap Permukiman & $\mathbf{9 \%}$ & Sangat berpengaruh \\
\hline Jarak terhadap Sungai & $\mathbf{8 \%}$ & Sangat berpengaruh \\
\hline Petani Karet & $\mathbf{8 \%}$ & Sangat berpengaruh \\
\hline Daerah Rawan Bencana & $5 \%$ & Kurang berpengaruh \\
\hline Sarana Pendukung & $5 \%$ & Kurang berpengaruh \\
\hline Jaringan Listrik & $\mathbf{1 6 \%}$ & \\
\hline Sumber Air & $\mathbf{8 \%}$ & Sangat berpengaruh \\
\hline Aksesibilitas & $\mathbf{8 \%}$ & Sangat berpengaruh \\
\hline Sarana Jalan & $\mathbf{1 4} \%$ & \\
\hline Fungsi Jalan & $\mathbf{7 \%}$ & Cukup berpengaruh \\
\hline Nilai Lahan & $\mathbf{7 \%}$ & Cukup berpengaruh \\
\hline Kedekatan Jaringan Jalan & $\mathbf{1 2} \%$ & \\
\hline Kedekatan Infrastruktur & $\mathbf{6 \%}$ & Cukup berpengaruh \\
\hline Total & $\mathbf{6 \%}$ & Cukup berpengaruh \\
\hline Sumber: Hasil Analis, 2014 & $\mathbf{1 0 0 \%}$ & \\
\hline
\end{tabular}

Sumber : Hasil Analisis, 2014

Peta dari setiap indikator selanjutnya ditampalkan (overlay) dengan menggunakan weighted overlay pada Spatial Analyst Tools dari Arc GIS 10.1. Hasil dari weighted overlay adalah berupa Peta klasifikasi lokasi industri olahan karet UIKM dengan value 2-4. Berdasarkan nilai 
tersebut maka klasifikasi lokasi industri olahan karet dibagi kedalam 3 kriteria yaitu bukan lokasi industri (nilai 2), hampir calon lokasi industri (nilai 3) dan calon lokasi industri (nilai 4).

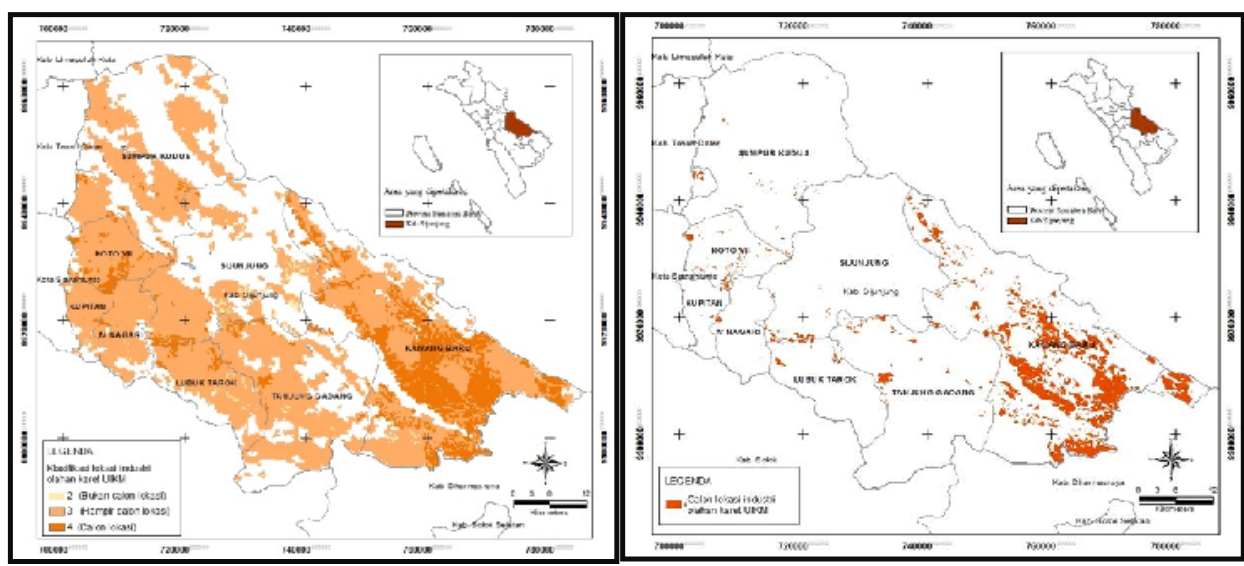

Sumber : Hasil Analisis, 2014

\section{GAMBAR 5}

PETA KLASIFIKASI LOKASI DAN PETA CALON LOKASI INDUSTRI OLAHAN KARET UIKM DI KABUPATEN SIJUNJUNG

Peta calon lokasi industri tersebut ditampalkan (overlay) dengan peta buffer jalan dengan kriteria seperti pada Tabel VI. Pada penelitian ini diasumsikan harga bahan bakar solar yang digunakan pada mobil pick up L300 adalah Rp 7.500,-/liter dan 1 liter solar dapat menempuh jarak $10 \mathrm{~km}$. Hal ini berarti bahwa biaya bahan bakar (biaya transportasi) yang harus dikeluarkan petani dari lokasi industri ke jalan adalah $\mathrm{Rp} 750,-/ \mathrm{km}$.

TABEL 6

BIAYA TRANSPORTASI DARI JALAN KE LOKASI INDUSTRI KARET

\begin{tabular}{|r|r|}
\hline \multicolumn{1}{|c|}{$\begin{array}{c}\text { Jarak Jalan ke Lokasi } \\
\text { Industri Karet (m) }\end{array}$} & $\begin{array}{r}\text { Biaya Transportasi } \\
\text { (Rp) }\end{array}$ \\
\hline 500 & 375 \\
\hline 1.000 & 750 \\
\hline 2.000 & 1.500 \\
\hline 3.000 & 2.250 \\
\hline
\end{tabular}

Sumber : Hasil Analisis, 2014

Tahap selanjutnya adalah melakukan overlay (intersect) antara Peta Jarak Calon Lokasi Industri Olahan Karet UIKM dengan Peta Buffer Perkebunan Karet di Kabupaten Sijunjung.

TABEL 7

BIAYA TRANSPORTASI DARI KEBUN KARET

\begin{tabular}{|r|r|}
\hline Buffer Perkebunan Karet (m) & Biaya Transportasi (Rp) \\
\hline 500 & 375 \\
\hline 1.000 & 750 \\
\hline 1.500 & 1.125 \\
\hline
\end{tabular}

Sumber : Hasil Analisis, 2014 


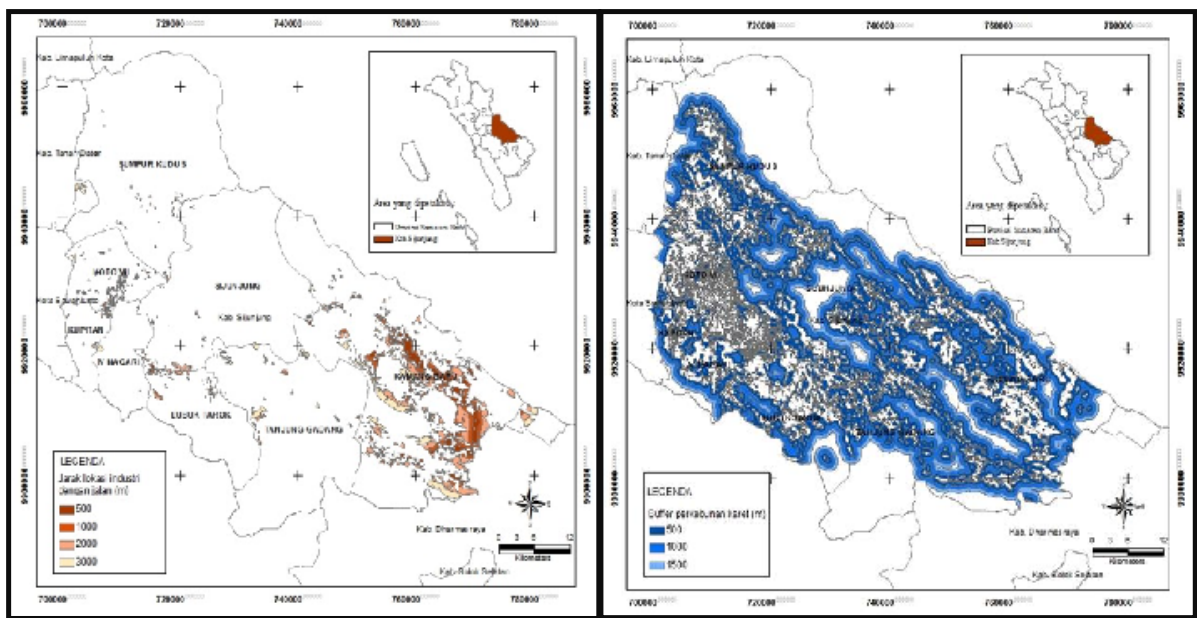

Sumber : Hasil Analisis, 2014

\section{GAMBAR 6}

PETA JARAK LOKASI INDUSTRI OLAHAN KARET UIKM DARI JALAN DAN PETA BUFFER PERKEBUNAN KARET DI KABUPATEN SIJUNJUNG

Berdasarkan hasil overlay maka total biaya transportasi diklasifikasikan menjadi 3 kriteria yaitu rendah, sedang dan tinggi seperti yang terdapat pada Tabel 8 .

TABEL 8

KLASIFIKASI TOTAL BIAYA TRANSPORTASI

\begin{tabular}{|l|l|}
\hline Range & Klasifikasi \\
\hline $750-1.625$ & Rendah \\
\hline $1.625-2.500$ & Sedang \\
\hline $2.500-3.375$ & Tinggi \\
\hline \multicolumn{2}{|l}{ Sumber : Hasil Analisis, 2014}
\end{tabular}

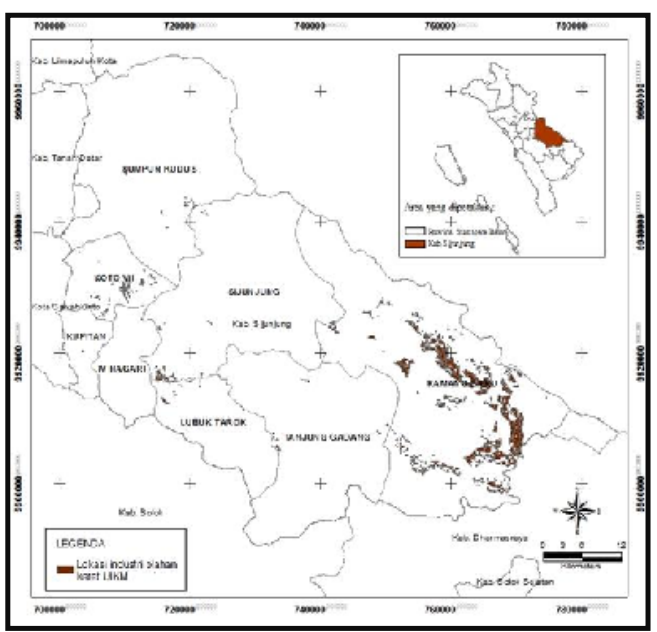

Sumber: Hasil Analisis, 2014

\section{GAMBAR 7}

PETA LOKASI INDUSTRI OLAHAN KARET UIKM DI KABUPATEN SIJUNJUNG

Hasil analisis tersebut menjelaskan bahwa terdapat 7 Kecamatan (Kamang Baru, Lubuk Tarok, Koto VII, Tanjung Gadang, Sumpur Kudus, Sijunjung, Kupitan) atau 31 Nagari yang 
layak sebagai lokasi industri olahan karet UIKM di Kabupaten Sijunjung dengan luas lahan berkisar $1 \mathrm{Ha}-1.954 \mathrm{Ha}$. Sebagian besar lahan pada 7 Kecamatan tersebut merupakan semak belukar dan kebun campuran. Keunggulan lokasi tersebut antara lain dekat dengan sarana jalan (0-1.000 m dari jalan), dekat dengan sungai (500-1.000 m dari sungai), dilalui oleh jalan arteri primer, kolektor dan lokal primer, tersedia jaringan listrik, bukan daerah rawan bencana, jauh dari permukiman penduduk, produksi karet cukup besar, dan berada pada kemiringan lereng kurang dari $25 \%$.

\section{Evaluasi Lokasi Industri Olahan Karet UIKM Terpilih dengan RTRW Kabupaten Sijunjung}

Rencana Tata Ruang Wilayah (RTRW) Kabupaten Sijunjung Tahun 2011-2030 menjelaskan bahwa lokasi industri agro di Kabupaten Sijunjung diarahkan di Kecamatan IV Nagari dan Kamang Baru khususnya Kiliran Jao dengan pertimbangan antara lain jaringan transportasi yang mudah dan dekat dengan sumber bahan mentah. Lokasi tersebut kemudian ditampalkan (overlay) dengan peta lokasi industri olahan karet UIKM terpilih. Hasil dari overlay tersebut menunjukkan bahwa terdapat sedikit kecocokan antara arahan RTRW Kabupaten Sijunjung dan lokasi industri hasil penelitian yaitu di Kecamatan Kamang Baru. Namun dalam arahan RTRW Kabupaten Sijunjung terdapat 3 Nagari di Kamang Baru yang menjadi lokasi agroindustri yaitu Nagari Takung (Kiliran Jao), Sungai Lansat dan Lubuk Tarantang. Namun hasil penelitian menunjukkan bahwa Nagari Lubuk Tarantang tidak cocok dijadikan lokasi industri dikarenakan tidak tersedia aliran listrik, kawasan hutan lindung dan jauh dari jaringan jalan. Selain itu Kecamatan IV Nagari juga kurang sesuai direkomendasikan sebagai lokasi industri karet UIKM karena terletak sangat dekat dengan permukiman (kurang dari $1 \mathrm{~km}$ dari permukiman) dan produksi karet pada wilayah tersebut cukup rendah sehingga tidak menjamin kontinuitas produksi karet.

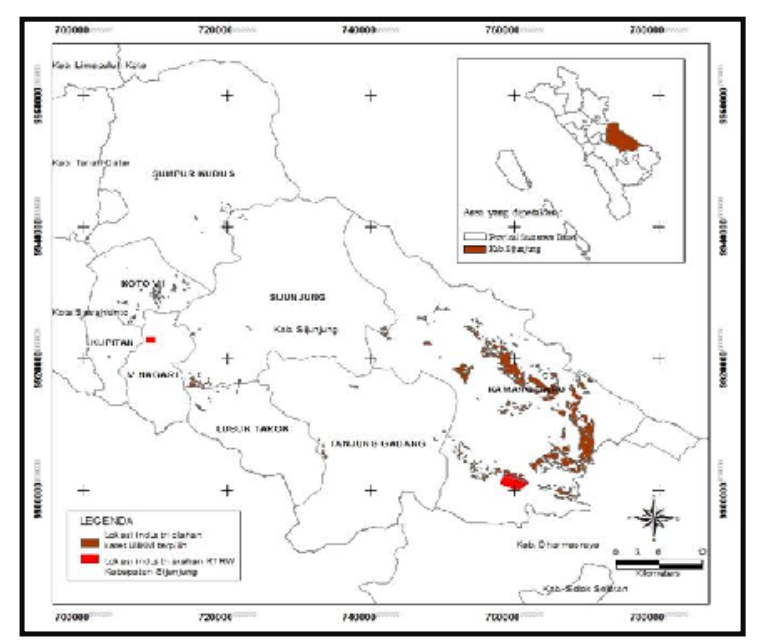

Sumber : Hasil Analisis, 2014

GAMBAR 8

PETA EVALUASI LOKASI INDUSTRI OLAHAN KARET UIKM TERPILIH DENGAN RTRW KABUPATEN SIJUNJUNG

\section{Penentuan Lokasi Industri Olahan Karet UIKM di Kabupaten Sijunjung}

Berdasarkan hasil evaluasi lokasi industri olahan karet UIKM terpilih dengan RTRW Kabupaten Sijunjung maka wilayah yang paling diprioritaskan menjadi lokasi industri olahan karet UIKM di Kabupaten Sijunjung adalah Kecamatan Kamang Baru, terutama Nagari Sungai Lansek dan Nagari Takung. 


\section{KESIMPULAN}

Berdasarkan hasil kajian dan analisis penentuan lokasi industri olahan karet UIKM di Kabupaten Sijunjung, maka dapat disimpulkan sebagai berikut :

1. Calon lokasi industri olahan karet UIKM mayoritas terdapat pada Kecamatan Kamang Baru (terutama Nagari Kunangan Parik Rantang, Kamang Baru, Maloro, Aia Amo, Takung), Koto VII (Nagari Limo Koto, Padang Lawas), Lubuk Tarok (Nagari Lalan). Lokasi tersebut memiliki beberapa keungulan antara lain berada pada daerah datar (< slope 25\%), memiliki produksi karet terbesar, berada jauh dari permukiman $(>2 \mathrm{~km})$, dekat dengan sungai $(<2 \mathrm{~km}$ dari sungai), tidak pada daerah rawan bencana, tersedia jaringan listrik, dan dekat dengan jalan arteri dan kolektor primer sehingga cocok dijadikan calon lokasi industri.

2. Lokasi industri olahan karet UIKM yang memberikan biaya transportasi minimum terdiri dari 7 Kecamatan (31 Nagari) yaitu Kecamatan Kamang Baru, Lubuk Tarok, Koto VII, Tanjung Gadang, Sumpur Kudus, Sijunjung dan Kupitan dengan biaya transportasi berkisar Rp 750,00 - Rp 1.500,00.

3. Evaluasi lokasi industri olahan karet UIKM terpilih dengan Rencana Tata Ruang Wilayah (RTRW) Kabupaten Sijunjung Tahun 2011-2030 dapat diketahui bahwa penetapan Kecamatan Kamang Baru sebagai lokasi potensial industri sesuai dengan hasil penelitian. Namun penetapan Kecamatan IV Nagari tidak sesuai direkomendasikan sebagai lokasi industri karet dikarenakan sangat dekat dengan permukiman (kurang dari $1 \mathrm{~km}$ dari permukiman) dan produksi karet pada wilayah tersebut cukup rendah sehingga tidak menjamin kontinuitas produksi karet.

4. Penentuan lokasi industri olahan karet UIKM di Kabupaten Sijunjung dapat dititikberatkan pada Kecamatan Kamang Baru khususnya Nagari Sungai Lansek dan Takung karena daerah tersebut merupakan daerah yang diizinkan oleh Pemerintah Daerah untuk pembangunan agroindustri.

\section{DAFTAR PUSTAKA}

Badan Perencanaan Pembangunan Daerah Kabupaten Sijunjung. 2010. Rencana Tata Ruang Wilayah Kabupaten Sijunjung 2011-2031. Sijunjung: Badan Perencanaan Pembangunan Daerah Kabupaten Sijunjung.

Siswita, Yeni. 2013. "Kelayakan Finansial Industri Pengolahan Karet Berbasis UIKM di Kabupaten Sijunjung”. Tesis tidak diterbitkan, Program Studi Ekonomi Pembangunan, Fakultas Ekonomi Universitas Andalas, Padang.

Sjafrizal. 2008. Ekonomi Regional. Padang: Baduose Media.

Soehardi, Sigit. 1987. Industri Kecil Sebuah Tinjauan dan Perbandingan. Jakarta: Bina Aksara. 